\title{
Conradian quest versus dubious adventure: Graham and Barbara Greene in West Africa
}

\section{Valerie Kennedy}

To cite this article: Valerie Kennedy (2015) Conradian quest versus dubious adventure: Graham and Barbara Greene in West Africa, Studies in Travel Writing, 19:1, 48-65, DOI: 10.1080/13645145.2014.994927

To link to this article: https://doi.org/10.1080/13645145.2014.994927

曲 Published online: 05 Mar 2015.

Submit your article to this journal $\pi$

Щ Article views: 70

View Crossmark data \lceil 


\title{
Conradian quest versus dubious adventure: Graham and Barbara Greene in West Africa
}

Valerie Kennedy*

\begin{abstract}
Graham Greene's Journey Without Maps (1936) largely conforms to the masculine tradition of imperialist travel writing, where the male protagonist emerges as the (sometimes conflicted) hero of his own narrative. Much of Journey Without Maps explores Liberia and Greene's psyche, creating parallels between Africa, the narrator's childhood, and the childhood of the human race, and embodying these parallels in a dense web of tropes and allusions. By contrast, as a woman, Barbara Greene is much less implicated in the imperialist tradition of travel writing, and at times Too Late to Turn Back disrupts some of the assumptions of this tradition through the demystification of the trope of adventure and excitement, the sporadic mockery of self and others, the self-deprecation, and the greater emphasis on reciprocity than is to be found in Journey Without Maps.
\end{abstract}

Keywords: travel writing; Africa; imperialism; allusions; adventure; childhood; gender roles

\section{Introduction}

Graham and Barbara Greene spent three months travelling in Sierra Leone and Liberia from January to March 1935. Out of that journey came Graham Greene's Journey Without Maps (1936) and Barbara Greene's Too Late to Turn Back, originally published as Land Benighted (1938). Graham Greene's journey originally had a political purpose - the investigation of allegations of enslavement of the Krus by the Liberian government (Butcher 2012; Shelden 1994, 156-160; Sherry $1989,510-513$ ), but it was also motivated by a desire to escape the pressure of both writing and of life in England, the latter described by Paul Fussell as the "I Hate It Here" feeling (1980, 15-23). Yet the finished Journey Without Maps is in large part a Conradian quest for the self, offering a primitivist, textual version of Africa (Dodd 1982, 131; Wittman 2011, 44, 45), framed by satirical portraits of the "Coast", notably the capital cities of Freetown and Monrovia. Too Late to Turn Back recounts a journey begun as a champagne-fuelled jaunt; the account of the experience, however, sporadically demonstrates a mockery of self and others which often undermines the idea of the journey as masculine imperialist quest or adventure which characterises Graham's account. The tropes of maps (Blanton 1997, 63-64; Fussell 1980, 65-66; Mikkonen 2007, 295-297; Thacker 2002), and of the parallels between the physical and psychological journeys (Dedet and Petr 1992, 331-332; Schwartz 2002, 28) in Journey Without Maps, have been frequently discussed, though usually only in brief, but Barbara's book has been largely ignored, with the exception of Paul Theroux's ([1981] 1990) introduction to Too Late to Turn Back (1990b, xxixxxiii), the brief analysis by Bernard Schweizer (2001, 71-75), and occasional short discussions, including one paragraph by Wittman $(2011,51)$.

*Email: kennedy@bilkent.edu.tr 
Journey Without Maps largely conforms to the masculine tradition of imperialist travel writing, where the male protagonist emerges as the (sometimes conflicted) hero of his own narrative. Much of Journey Without Maps explores Liberia and Greene's psyche, creating parallels between Africa, the narrator's childhood, and the childhood of the human race, and embodying these parallels in a dense web of tropes and allusions, some of which have been listed but not analysed by Blake $(1991,199)$. These tropes and allusions articulate both the narrator's critique of colonial Sierra Leone and Liberia and a version of the primitivist vision of Africa typical of imperialist traditions of writing and exploration. Greene frequently sees Africa in terms of English realities and constantly notes colour and race, while Barbara's presence is largely ignored, and Greene's own psyche takes centre stage.

Too Late to Turn Back is far less sophisticated in its narrative form than Journey Without Maps. There is no equivalent in Barbara Greene's text to the self-conscious psychoanalytic structure of "going back" in time in terms of both ontogeny and phylogeny while going forward in space which characterises Journey Without Maps and whose genesis Greene discusses in Ways of Escape (1980). Barbara Greene's book is straightforwardly chronological and episodic, with occasional discussions of local manners and customs. As a woman, Barbara Greene is much less implicated in the primitivist and imperialist tradition of travel writing to which Graham Greene largely belongs, and at times Too Late to Turn Back disrupts some of the assumptions of this tradition. Although the trope of the African as child aligns Barbara's book with an imperialist worldview, the lack of obsessive notations of colour and race, the demystification of the trope of adventure and excitement, the sporadic mockery of self and others, the self-deprecation, and the greater emphasis on reciprocity, all distinguish Barbara Greene's discourse from that of her cousin. These features, which are also to be seen in other writings by women travellers (see Blake 1992, 29; Foster 1990, 19; Mercer 1999, 148), may be said to offer a counter-tradition or counter-discourse to that of masculine imperialist travel writing, although (or perhaps because) some of these features seem to conform to conventional feminine gender roles.

This essay will argue that, with the exception of Bernard Schweizer's analysis (2001, 67-71, 148-151), the imperialist dimension of Journey Without Maps has been frequently mentioned but insufficiently analysed (Meyers 1990, 54; Schweizer 1998, 103; Thacker 2002, 20; Wittman 2011, 56), and that Too Late to Turn Back offers an implicit critique of masculine imperialist discourse on Africa thanks to the factor of gender, although, as Wendy Mercer argues, gender must be considered in relation to other factors such as class, age and education which also play key roles $(1999,147)$. In the case of the Greenes, the gender difference is partially countered by their shared upper-middle-class background which arguably predisposes them to see the Africans they employ as children, in accordance with traditional imperialist ideology. Blake (as quoted in McEwan 2000,33) makes the connection between class and imperialism in relation to women travellers, but the connection can be seen in the work of both the Greenes, although in Barbara's book the African as child trope is partially qualified by other patterns of imagery. While Journey Without Maps uses the discourse of masculine and imperialist superiority, even if this is ironised at times, Too Late to Turn Back offers intermittent mockery of the values inscribed in such discourse. While Barbara Greene often endorses conventional feminine gender roles (by emphasising reciprocity, the role of the woman as mother-figure, or even the alignment of femininity with potential madness), her mockery of the postures and performance of colonial authority debunks the imperialist worldview of many male-authored travel texts, including that of Journey Without Maps.

\section{Exploration versus adventure}

One of the most significant tropes in Journey Without Maps is that of "going back". As Christopher L. Miller remarks in relation to Greene's predecessor, Joseph Conrad, the phrase "travelling 
back" is "a paradigm of Africanist narration" $(1985,171)$. For Greene, Africa represents "a stage further back" or "the past from which one has emerged" ([1936] 2002, 19, 20), thus exhibiting what Johannes Fabian calls the "denial of coevalness", that is, anthropology's "tendency to place the referents of anthropology in a Time other than the present of the producer of anthropological [or in this case imperial travel] discourse" ([1983] 2002, 31). Greene repeatedly emphasises that there are no satisfactory maps of Liberia so that the journey is a journey into the unknown $(16,21,45-46)$ : the country "has never been properly mapped" (45), the British General Staff map offers "a blank space", while the map issued by the United States War Department is "Elizabethan in its imagination", inscribed with things like "Dense Forest" and "Cannibals" so that "one expects to find Eldorado" (46); the reference to Eldorado being the first of several to Sir Walter Ralegh's travelogue on Guiana. Greene uses the lack of satisfactory maps to suggest that his journey is exploration, not tourism, and also to link the physical journey through West Africa to the exploration of his own psyche. Midway through the text Greene describes psychoanalysis as "a long journey backwards without maps" (97), thus amplifying the book's second epigraph: "The life of an individual is in many respects like a child's dissected map", and recalling his description of childhood in "The Lost Childhood" as "a wild jungle country without a map" ([1947] 1969, 17).

However, Greene's text also indirectly (and presumably unintentionally) undermines this construction of the journey as an exploration of unknown territory by periodically noting that for over half of the way he and Barbara follow the route of the now more or less forgotten British traveller, Sir Alfred Sharpe. Greene tells us that he followed Sharpe's route in Liberia "at the start" ([1936] 2002, 67); nearing Kpangblamai, he informs us that he is "still following roughly the route which Sir Alfred Sharpe took in his journey through Liberia in 1919" (109), a comment repeated later in relation to Pandemai (118). Approaching Zigita, Greene notes that the road is "as hard and rough, according to Sir Alfred Sharpe, as any in Africa" (134). It is only when they approach Ganta, past the halfway point in their journey, that Greene says, with some satisfaction: "We were now at last off the route followed by other English travellers, for Sir Alfred Sharpe in 1919 went up northwards into French Guinea" after this (164, my emphasis). So, although Greene stresses the lack of maps or their inadequacy throughout the book $(16,21$, $45-46,48,50,107,114,124,174)$, he also indirectly acknowledges that he and his cousin follow in the footsteps of a relatively recent traveller for over half their route, thus undermining his statement in Ways of Escape that it was "a slow footsore journey into an interior literally unknown" (1980, 39). As Greene explains in Ways of Escape, he wished to avoid "the awful tedium of A to Z" of travel writing and so he constructed the book as two parallel journeys, the physical trek and the "completely personal" psychological journey linked to "memories, dreams, word-associations", so that "the journey became more general" because, "if Jung is to be believed we share our dreams" (39). Here Greene presents his recreation of the journey as a dramatisation of the Jungian collective unconscious, couched in the imperialist tropes of exploration and adventure. Interestingly, Paul Fussell endorses Greene's romanticised selfimage as explorer when he writes that "he had to travel (explore would be a better word) with virtually no maps" (1980, 65-66), seemingly not noticing or ignoring the references to Sharpe's earlier journey.

On another level, Journey Without Maps revels in its own belatedness. The allusions to Joseph Conrad's Heart of Darkness and to Sir Walter Ralegh's The Discoverie of the Large, Rich and Bewtiful Empyre of Guiana, the narrator's insistence that Africa represents both the childhood of the human race in its "primitive" state and Graham Greene's own repressed childhood fears, combine to create an image of Africa which is familiar as a trope of imperialist writing about Africa: the dark continent. As Patrick Brantlinger says, “Africa grew 'dark' as Victorian explorers, missionaries, and scientists flooded it with light, because the light was refracted 
through an imperialist ideology that urged the abolition of 'savage customs' in the name of civilization" (1986, 185; see also Blake 1991, 199). Journey Without Maps begins and ends with allusions to Heart of Darkness, and the phrase is also used in relation to the secret societies of Liberia (Greene [1936] 2002, 19, 248, 173). Before leaving London, Greene characterises a journey to Africa as a search for something for which "there are a thousand names ... King Solomon's Mines, the 'heart of darkness' if one is romantically inclined ... or one's place in time" (1920). The allusion to King Solomon's Mines presumably refers both to the Biblical references to the mines of Ophir in 1 Kings 9: 28 and 10: 11 (King James Bible) and to Rider Haggard's 1885 novel, thus both situating Greene's text in relation to a long-established tradition of Africanist primitivism and recalling one of Greene's favourite authors. In "The Lost Childhood" Greene identifies King Solomon's Mines as one of the most important books of his childhood; he also singles out "the ancient witch Gagool", adding: "Gagool I could recognize - didn't she wait for me in dreams every night, in the passage by the linen cupboard, near the nursery door?" ([1947] 1969, 15), an image which recurs in Journey Without Maps. Although Greene does intermittently acknowledge the "strangeness" and incomprehensibility of Africa $(33,88,95,115)$, when he is about to leave Liberia he asserts that Africa "had never been really strange" because "The 'heart of darkness' was common to us both", since it represents "those ancestral threads" which "Freud has made us conscious [of]" and which are the reason why so many travellers and explorers have felt the "need ... to go back, and begin again" (248). Here the tropes of going back and the "heart of darkness" combine as Greene lists the travellers and writers who have previously felt this need either consciously (Arthur Rimbaud and Conrad) or unconsciously (Mungo Park, David Livingstone, and Henry Morton Stanley) as he explicitly situates himself in the tradition of (sometimes self-critical) imperialist African exploration and travel writing.

Another feature of Journey Without Maps which situates it in this tradition are the constant parallels between the customs of the interior of Liberia, Greene's own childhood past, and the past of the human race. For example, Greene compares the masked blacksmith of Mosambolahun to a Jack-in-the Green whom he saw when he was four years old:

here in Liberia again and again one caught hints of what it was we had developed from. It wasn't so alien to us, this masked dance .... One had the sensation of having come home, for here one was finding associations with a personal and a racial childhood, one was being scared by the same old witches. ([1936] 2002, 93, my emphasis; see also 61, 68, 74, 158; Mikkonen 2008, 309, 312; Schwartz 2002, 28; Thacker 2002, 20).

A little later, again linking witches, childhood, and Africa, Greene recounts a recurrent childhood dream:

I would be walking along a dark passage to the nursery door. Just before the door there was a linencupboard and there the witch waited, like the devil in Kpangblamai, feminine, inhuman. ... Now I seemed to be back in the dark passage: I had to see the witch. (119)

This passage, and others like it, illustrate Marianna Torgovnick's point that, thanks to Sigmund Freud's description of the primitive as "a necessary stage of development through which every race has passed", the primitive represents "an exotic world which is also ... familiar" $(1990,8)$. Moreover, one might argue, like Fabian, that "Primitive being essentially a temporal concept, is a category, not an object, of Western thought" ([1983] 2002,18). When Greene describes the Kpangblamai devil and the witch of his childhood as "feminine, inhuman", he makes them both uncanny, familiar and unfamiliar, homely and strange, and his words recall Freud's comment in "The Uncanny" that "the uncanny element ... arises either when repressed childhood 
complexes are revived by some impression, or when primitive beliefs that have been surmounted appear to be once again confirmed" ([1919] 2003, 155).

Schweizer offers a more political reading of the uncanny in Journey Without Maps when he argues that "the deeper that Greene penetrated into the realm of 'the primitive', the more he reverted to a political ethos that marked the return of an 'earlier system of belief'", that is, Greene's earlier conservatism as manifested, for example, in his becoming a special constable at the time of the General Strike in $1926(2001,149,61)$. But Schweizer seems to over-emphasise the political dimension of Journey Without Maps. While he is right to point out that one of Greene's initial purposes in travelling to Liberia was to investigate the allegations of slavery and mistreatment of the Krus, he is speculating, even if he is right, when he asserts that "it is very likely that [Greene] intended to write an investigative report about the country's political troubles" (my emphasis). Greene never wrote such a report, and to view Journey Without Maps as primarily a book with "a manifest political message", "masquerading as a psychological repression" seems perverse, especially since Schweizer elsewhere admits that the explicit "condemnation of imperialism" is limited to "the beginning and ... the end of the trip", while in the interior Greene "is at a loss as [sic] to sort out his political principles" $(65,147,70)$. Schweizer declares that Greene's statement in Ways of Escape that Journey Without Maps was not "a political book in the sense that Gide's Voyage au Congo was political" "has a defensive ring about it", but this seems an unjustified interpretation of Greene's words, especially since Schweizer then admits that the "politically relevant core" of Greene's book is "ambivalent and unstable" (65). I would argue that in the interior of Liberia Greene regresses not only to a general conservatism but also to a set of imperialist attitudes, although he also satirises them even as he conforms to them. In sum, then, much of Journey Without Maps constructs a familiar image of the interior of Africa through the tropes of the journey into the unknown, the "heart of darkness", and the parallels between Greene's own past, the past of England and that of the human race.

Too Late to Turn Back is also patterned by recurring tropes, images and allusions. Two of the most important tropes are those of excitement and adventure, which also appear in the Foreword that Barbara wrote for the 1981 edition (Greene [1981] 1990a xiii), and which her text both endorses and questions. This may be seen as an example of the way in which the discourses of women's travel texts, as Sara Mills says, "both disclose the nature of the dominant discourses and constitute a critique from its [sic] margins" (as quoted in McEwan 2000, 12), although in Barbara Greene's case, the criticism is generally implicit. Moreover, in Too Late to Turn Back there are also references to films and cartoons which are often used mockingly or humorously to debunk the seriousness of the whole enterprise, thus implicitly undermining the trope of the journey as masculine, imperialist quest.

Initially, Barbara Greene seems to endorse the excitement and adventure tropes. Before they leave England she is "full of the most glorious excitement" (Greene [1981] 1990b, 3); on the boat she is excited by the "tropical nights", the news of a yellow fever outbreak, and Graham's dismantling of her ideas, and after the first day of the journey she declares:

It was a wonderful and exciting trek. Everything was still new, and thrilled me.... I still had that champagne feeling with which I had entered this adventure. $(4,5,7,37,38)$

On the second day of the trek, like Graham, she revels in being "away from Europe and all those things we call civilisation at last", cut off from news and communication: "All of which", she confesses, "gave [her] a childish feeling of satisfaction" (42).

Yet Barbara soon becomes aware that her excitement and the adventure trope are both belated and spurious, and she realises that despite her feeling of achievement, she is in fact 
"accomplishing no more than if I were sitting in an arm-chair at home" (Greene [1981] 1990b, 42). She continues:

I felt rather ashamed of myself for feeling excited at the thought that we would presently be walking through parts of the world that white people had probably not walked though before. I was truly ashamed at such a futile thought, but all the same I could not help being thrilled. I knew perfectly well that my journey through Liberia would bring no benefit whatsoever to humanity, and that certainly we would contribute nothing new to the scientific world. ... But it was like reading thrilling adventure stories in one's early school-days, when invariably one identified oneself with the hero. $(42-43)$

In fact, as Graham Greene's references to Sir Alfred Sharpe indicate, Barbara is wrong in thinking that no "white people" (one of the relatively few references to colour in her text) had ever passed that way before. Significantly she feels "ashamed" of her "futile" excitement since she recognises the pointlessness of the journey, and she also realises that the journey cannot be justified by any claim to increase the store of scientific knowledge, a frequent motivation of eighteenth- and nineteenth-century travellers (Mills 1994, 35). Furthermore, it is Barbara rather than Graham who explicitly locates one source of the "adventure" trope in "the thrilling adventure stories [of] one's early school-days", and at the same time she recognises that any simple identification with the hero is no longer possible for her as an adult. Graham Greene also identifies Haggard's King Solomon's Mines as one of the sources of the familiar tropes of quest and adventure and he goes on to adopt them himself, declaring in Ways of Escape that he belonged to "a generation brought up on adventure stories ... . so we went looking for adventure" by travelling (1980, 37). Barbara, however, demystifies the adventure trope by revealing that it no longer applies to their journey, warning the reader that he will not find in her book "the roaring lion type of adventure", since "The beasts of the forest kept away from us, the natives were friendly, our adventures were more amusing than frightening, and good luck dogged our footsteps most of the time"; in short, "The old type of Adventure in the Wilds seems to have disappeared" (43). She goes on to analyse very perceptively the popular version of the discursive tradition to which Graham Greene's Journey Without Maps belongs:

However excited I felt, however happy, so much of what I saw was in some vague way familiar, seen a hundred times in travel films and in geographical magazines. Nowadays if we want hair-breadth escapes we must turn again to the school-boy stories, written by men who have probably lived all their lives comfortably in England. (44)

Despite this deconstruction of the excitement/adventure trope, it does emerge once more in Too Late to Turn Back, when Graham and Barbara Greene get separated. Wondering why she is not more worried, Barbara realises that

I was revelling in the relief from the boredom of walking without excitement. Trekking today had been an adventure. (94)

A little later, reunited with Graham, the sense of adventure disappears:

I was feeling cheated, and too much looked after. Nothing exciting would ever happen, for something would always guard me. I was being too much cared for, like the baby of a large family. (94-95)

Barbara Greene is younger than her $\operatorname{cousin}^{1}$ and here she seems to deploy the adventure trope to implicitly criticise Graham's total control of the journey which prevents her from taking any 
initiative or any part in the decision-making, although elsewhere she gratefully acknowledges that he has to do all the work $(153,157)$. Since she seems more in touch with popular culture, and also since she is more distanced by her gender from the narrative tradition of the boys' adventure story despite her childhood enjoyment of it, Barbara demystifies the discursive source of the "adventure" and "journey into the unknown" tropes, thereby implicitly criticising masculine imperialist discourse and the values it embodies.

Thus, while seeing her Liberian experience as an adventure, Barbara Greene also realises that such an idea is second-hand, belated and spurious. Whereas Graham Greene uses various primitivist tropes to explore the connections between his vision of Africa, the human past, and his own childhood, Barbara both uses and partially subverts the discourse of adventure. Both of them also explore the meaning of Africa in relation to England or Europe, albeit in different ways.

\section{The meaning of Africa: oppositions and allusions}

In both Journey Without Maps and Too Late to Turn Back the comparisons between Africa and England are often to the advantage of Africa. In both texts, but more emphatically in Graham's, the real countries of Sierra Leone and Liberia are reconstructed in terms of what Edward Said calls "imaginative geography": two African countries become divided into Africa (the authentic interior) versus the Coast (the Westernised and seedy colonial capital cities). This conforms to the process which Said defines as the "universal practice of designating in one's mind a familiar space which is 'ours' and an unfamiliar space beyond 'ours' which is "theirs" ([1978] 1995, 55, 54), with the Coast in Journey Without Maps equating to "the familiar space which is "ours"". For Graham the comparisons are obsessive and frequently linked to the allusions through which he explores the relative levels of civilisation of Africa and England or Europe. For Barbara, by contrast, the comparisons and the allusions construct her experiences in Africa through the lens of musical comedy or film, often revealing a self-deprecating humour which is not to be found in her cousin's text and which can be compared to the description that Wendy Mercer offers of Léonie D'Aunet who "is able to laugh at herself, inviting the reader to do likewise" $(1999,158)$. But the humour in Too Late to Turn Back at times also mocks the journey as a whole and especially Graham's role as "Great White Chief" (Greene [1981] 1990b, 183).

In the Liberian interior Graham Greene constantly compares Africa to England. While some of these comparisons use the obvious strategy of seeing the unfamiliar through the familiar, others are more complex. Examples of the former are the bush which is "as ragged and uninteresting as a back garden which has been allowed to run wild and in which the aspidistras from the parlour have seeded and flourished among the brown-scorched grasses and the tall wrinkled greenery" (Greene [1936] 2002, 53 and see 156), "a tiny plateau" which is "not much larger than the Round Pond in Kensington Gardens" (114), the African messengers who are "as reliable as the English Post Office" (64), the headman of one village who is "very like an English foreman" (102), and one of the carriers whom Greene imagines as "a season-ticket-holder, the reliable support of his mother and sisters in a remote sad suburb" (110). An example of the second, more interesting type of comparison involving a literary allusion, occurs when Greene says: "I was happy with the sense that every step was towards home, there was something peculiarly English about the fish, the pond, the quite small trees" (182). As the landscape description continues, Africa is transformed into a fictionalised, out-dated England:

A quarter of a mile away the forest wall set a limit to England, and across the stream in single file came a few men, naked except for their loin-cloths, carrying bows and steel-tipped arrows. It was like the world of Miss Nesbit, where odd savage people appear in country lanes; they might have been coming 
through the Amulet out of the African forest into an English park. We passed them, going ourselves into Africa, while they with their bows and arrows, their naked cicatrized bodies, went on into the park, towards the great house and the butler's pantry. (182)

The allusion to Edith Nesbit, the popular Edwardian children's writer, seems to confuse two or more of her works. The Amulet is central to The Story of the Amulet but the incident where "odd savage people appear in country lanes" is found in Five Children and It and involves "Red Indians" not Africans ([1902] 1994, 153 and see 153-164). In The Phoenix and the Carpet the children do encounter "savages", but on a sunny island to which the carpet magically transports them, not in England (Nesbit [1904] 1959, 69). Moreover, the England of "the great house and the butler's pantry" is not to be found in Nesbit's works, where the children's adventures generally occur when their parents are in financial difficulties. This confused allusion to Edith Nesbit seems to indicate that Greene's vision of England here is idealised, anachronistic and class-bound. By 1936 the age of "the great house and the butler's pantry" was in its last stages, as the works of Greene's contemporary, Evelyn Waugh, confirm. Moreover, the allusion to Nesbit's works, with their middle-class children's "adventures" and their English supremacist and elitist worldview, again aligns Greene's text, incongruously, with a domesticated version of the imperialist discursive tradition, children's fiction.

Graham Greene also uses allusions to create an image of Africa as an alternative to Western modernity. In Dakar, in order to express this vision, he translates some of the key words of Baudelaire's "L'Invitation au voyage", "Là, tout n'est qu'ordre et beauté,/Luxe, calme, et volupté" ([1857] 1991, 99-100), to describe his "first sight of Africa" as "a sense of warm and sleepy beauty, of enjoyment divorced from activity and the weariness of willing" (33). Even though for him the African interior possesses "A quality of darkness ... of the inexplicable" and "an unexplained brutality" (Greene [1936] 2002, 20), he still sees the continent as representing a positive alternative to the wrong direction that Europe has taken:

Today our world seems peculiarly susceptible to brutality. There is a touch of nostalgia in the pleasure we take in gangster novels, in characters who have so agreeably simplified their emotions that they have begun living again at a level below the cerebral. We, like Wordsworth, are living after a war and a revolution, and these half-castes fighting with bombs between the cliffs of skyscrapers seem more likely than we to be aware of Proteus rising from the sea. It is not, of course, that one wishes to stay for ever at that level, but when one sees to what unhappiness, to what peril of extinction centuries of cerebration have brought us, one sometimes has a curiosity to discover if one can from what we have come, to recall at which point we went astray. (21)

Locating himself historically as living belatedly after World War I and the Russian Revolution, and comparing himself to Wordsworth in the process, Greene sees characters in gangster novels, like Africans, as representing an earlier stage of human development, of people living "below the cerebral" with "agreeably simplified" emotions. The oblique allusion to Wordsworth's sonnet "The World Is Too Much with Us", in the words "Proteus rising from the sea" indirectly valorises African simplicity and primitiveness. In the sonnet, after having argued that "we are out of tune" with "Nature", Wordsworth concludes:

Great God! I'd rather be

A Pagan suckled in a creed outworn;

So might I, standing on this pleasant lea,

Have glimpses that would make me less forlorn;

Have sight of Proteus rising from the sea;

Or hear old Triton blow his wreathed horn. ([1807] 2012, 347). 
Greene's indirect allusion to Wordsworth obliquely identifies both Africa and the gangster "halfcastes" with the world of classical mythology, of noble pagans, in opposition to the "unhappiness" and the "peril of extinction" which Greene sees as typical of Western modernity. The mention of the "unhappiness" of Western urban humanity recalls Freud's argument that much of modern humanity's unhappiness results from the repression and/or sublimation of the instincts required by civilisation ([1930] 1961, 51-52), while the words "peril of extinction" not only look back to the First World War, but also, proleptically, forward to the Second World War. Moreover, Greene's critique of the degeneration of European modernity is reinforced by quotations from T. S. Eliot's "Prufrock" and The Waste Land $(19,249)$ to suggest the alienation and the violent banality of the Western city. ${ }^{2}$

But it would be wrong to see Greene simply as an example of primitivism, although critics like André Dedet and Christian Petr (1992, 332-333), Simon Gikandi (1996, 179), Adam Schwartz (2002, 25-26, 32-34), and Emily Wittman (2011, 44) have done so, while Jeffrey Meyers (1990, 57) and Bernard Schweizer (2001, 69-70) see Greene as ambivalent about the primitive. Greene says explicitly that "It is not, of course, that one wishes to stay for ever at that level [that is, below the cerebral]" ([1936] 2002, 21), and at the end of Journey Without Maps he reiterates:

It isn't that one wants to stay in Africa: I have no yearning for a mindless sensuality, even if it were to be found there: it is only that when one has appreciated such a beginning, its terrors as well as its placidity, the power as well as the gentleness, the pity for what we have done with ourselves is driven more forcibly home. (249)

In the text as a whole, Liberia is at times characterised by the possibility of "mindless sensuality", by power and terror, but also by gentleness and placidity, but it is finally most important as an alternative to and a means of understanding "the pity of what we [Westerners] have done to ourselves".

The contrast between primitive Africa and degenerate modern Europe is complicated in both Greenes by a third term, the Coast, with its debased version of Western civilisation, or "the seedy", as Graham Greene calls it. Both Greenes can be related to the long tradition of Western travellers like Richard Burton ([1863] 1991, vol. 1, 206-212) and Mary Kingsley ([1897] 1988, 660-661) in their dislike of educated or Europeanised Africans and of the modernising effects of colonisation on the continent. Graham Greene calls these effects "seediness" and he is both fascinated and appalled by it in both Africa and Europe. In Journey Without Maps the word "seedy" is used to refer to several disparate phenomena: Liberian politics and a version of London ([1936] 2002, 19), the Liverpool hotel and Greene himself (22); "the seedy Pole in a singlet and a pair of dirty white trousers" (34-35) who boards the ship at Conakry, and the "seedy civilization" of the English settlers of Freetown in Sierra Leone (38). However, its primary function is to refer to the Coast of Africa, where the influence of European colonisation is most obvious.

Although Greene states that "seediness has a very deep appeal" because "it seems to represent a stage further back" in being closer to the simple communal life of the Liberian interior ([1936] 2002, 19), he also criticises the influence of Western civilisation on African culture. He declares that in Duogobmai "the coastal civilization had corrupted the natives" (129), that the Coast has made the Bassa men "liars, swindlers, lazy, weak, completely undependable" (218), and he identifies both homosexuality and prostitution as degenerate Western phenomena introduced to the interior by their contact with Western civilisation via the Coast $(195,215)$. None of these criticisms of the Liberian interior explicitly mentions colonialism. However, in Kailahun, Sierra Leone, Greene explicitly foregrounds British colonialism and its capitalist underpinnings: 
Civilization here remained exploitation ... Civilization so far as Sierra Leone was concerned was the railway to Pendembu, the increased export of palm-nuts; civilization, too, was Lever Brothers and the price they controlled; civilization was the long bar in the Grand, the sixpenny wages. (61)

Towards the end of the book, nearing the Coast, Greene states: "One was back, or, if you will, one had advanced again, to the seedy level" (224), meaning, presumably, that they have returned to where they started and regressed from the primitive innocence of the interior, or that they have "advanced" to a level nearer to Western civilisation. Greene remains equivocal as to whether or not the debased, Western-influenced civilisation of the Coast of Sierra Leone and Liberia represents progress over the life of the interior, although he is fascinated by the "starveling culture" of Liberia's capital, Monrovia, since he finds in it "a simplicity, a pathos" which "redeem[s] it from the complete seediness of a colony like Sierra Leone" (243). Greene's attitude to the oppositions between Africa and England or Europe is complex: Africa as seen in the Liberian interior functions as both a mandatory image of danger and power (the bush devils and secret societies, for example, see 89-93, 135-141, 173-177) but also of an earlier, more innocent communal life. Conversely, the Coast represents an in-between level, seen negatively in relation to the economic exploitation of colonialism, but also positively as a step on the way to the more appealing life of the interior.

Like Graham, Barbara Greene at times explicitly compares Africa to London or Europe, and she follows him in criticising the corruption of the simplicity of the interior by the "seedy" influence of the Coast. Generally her comparisons highlight the peace and simplicity of the Liberian interior as opposed to the "rush" of London, although occasionally she also remembers London's material comforts. At other times she views events and people in Liberia through theatrical or filmic metaphors, which often express her sense of the unreality of her experiences and/or use humour to deal with the unfamiliar or the potentially threatening. She also undermines the idea of superior masculine imperialist wisdom when she highlights the absurdity of the articles the Greenes have brought from England as "dash" for the Africans.

In an early evocation of her London world, she says that to find herself walking through Liberia "seemed rather unreal". She continues:

Any moment, I thought, I will wake up and find myself in London. I will look out of the window and see the usual damp and dreary January morning. My ancient maid will come in with some tea, and the bath water will probably be cold. I will open the paper and read that Europe is again on the verge of a crisis, that there has been another strike, that unemployment figures are going up, that there have been a few more murders most foul. (Greene [1981] 1990b, 16)

Her London life is represented by the banal and unappealing images of "damp and dreary" weather, cold bathwater, the crisis in Europe, strikes, unemployment and murder. More often, however, she contrasts "the rush of Europe" (24), or "our European ideas of haste and hustle" (15), with the timelessness and peace of Liberia, as when she tries to explain London life to Victor Prosser, the schoolteacher at Toweh Ta. She begins by describing "the crowds, the buses, the shops" and then "the underground railways", but she realises that he does not believe her, since he has never even seen an ordinary railway (147). She reflects:

He was right, of course. It was an impossible, crazy world that I had described. I laughed to myself to think that I had been such a fool as to imagine that I would find dangers in Liberia. Here it was safe and quiet. I looked round me and found nothing but peace. But the London I had described of crowds, and hurrying motor vehicles, noise and underground trains, that was terrifying. It all sounded horrible, and I almost felt that I did not want to go back - till, of course, I remembered Elizabeth Arden, my flat, and the Savoy Grill. (147-148) 
As a number of critics have argued, women travellers are more likely than men to establish relations of a "bond with the "other" (Mercer 1999, 148), or "reciprocity" (Blake 1992, 29) with the inhabitants of the countries they visit, thus potentially undermining the masculine imperialist discourse of authority. Barbara Greene is able to imagine what Victor Prosser is thinking and realises that her London might be "terrifying" and "horrible" to him compared to the "peace" of Liberia, although she soon remembers the middle-class luxuries of her London life.

Another example of reciprocity, and of the happiness which Barbara experiences in the Liberian interior, occurs in Nicoboozu, "a charming place and beautifully clean", where "everything was beautiful" and "It was impossible not to feel happy" (Greene [1981] 1990b, 56, 57). Here Barbara is able to establish friendly, although wordless, relations with the village girls: "Although we could exchange no word, we laughed together and felt friendly and happy", she writes (58). Although Schweizer observes that this scene, with its focus on "private lives", "will not do as an example of disruptive female travel writing" (2001, 73), I would argue that while the focus on personal relations does conform to the conventional feminine gender role, nonetheless the emphasis on reciprocity rather than isolation, mastery or conflict does implicitly criticise Graham Greene's representations of Africans which are largely (of necessity) dominated by the authority that he finds himself forced to exercise over them. At the end of the chapter, Barbara concludes:

I would like to linger over this evening, but there is nothing more one can say. Nothing happened. There was no sense of anticlimax. It was something perfect in itself. There was a moon and a native village, dancing, and naked black babies laughing. There were two white people watching and having their arms stroked from time to time. There was friendliness, and gaiety that came straight from the heart. And, wonder of wonders, there was a hut that night with no rats! (64)

Despite the notations of colour in "naked black babies" and "two white people", and the comic bathos of the final sentence, the passage establishes a vision of relationship between the Greenes and the Liberians which emphasises connection rather than distance, providing an example of the connection to people of other races at least partially outside the parameters of colonial authority structures, one which potentially challenges the hierarchical imperialist view of relations between races.

Some of Barbara Greene's other comparisons of Africa and England work through allusions to musical comedy, theatre or film, which often stress the unrealistic nature of her experiences or the comedy of the situation in which she finds herself, or both. Describing the hard walk up to Zigiter, she says: "I felt like some poor creature in a Walt Disney film, wending a heartbreakingly cruel way up a twisty, winding road to the wicked castle lying high up on the mountainside" ([1981] 1990b, 65). She goes on to personify the plants, the rocks and the animals, and she asks: "What chance had innocence against these overpowering forces of evil? Such futile weakness against so much strength?" and admits that a forest "shows one too clearly what one is in the world - a little scrap of nothing at all" (66). The feelings of powerlessness and insignificance expressed through such passages contrast with the discourse of exploration as "mastery, conquest and quest" which is characteristic of many masculine imperialist travellers (Lawrence as quoted in Siegel 2004, 9-10); a version of which characterises Graham Greene's text. Elsewhere, Barbara Greene uses theatrical metaphors to describe the unfamiliar through the familiar, but also to deflect troubling thoughts about what she is seeing. For example, in an extended theatrical metaphor, she describes the meeting with the drunken chief of Dijecke and his wives and daughters as "musical comedy", where "Bobby Howes [is] disguised as a black chief" (102 and see 102-106). Similarly, Colonel Davis is "too theatrical" to be considered as "a cold-blooded murderer of women and children", and instead looks like "the handsome villain in an old-fashioned melodrama" who will finally show that "underneath his dashing exterior there lies a heart of gold" 
(160). Here the stereotyped melodramatic allusion seems to act as a defence, preventing her from thinking about the fact that Colonel Davis has been found responsible for "wholesale murder and destruction" (163). This is also the case when she reacts to Dr. Harley's tale of cannibalistic practices by reflecting: "I could only think, with the same forgetfulness of good English as Alice in Wonderland, that everything was getting "curiouser and curiouser"' (121). Sometimes comedy takes over, as when Barbara compares herself to the old man in Treasure Island who can think of nothing but cheese when her own longing for smoked salmon comes to obsess her, when she hopes that they will not have to use the weapons they have with them because "[she] could not imagine [her] cousin in a Douglas Fairbanks role, fencing skilfully against a score of natives", or when she comments that Ganta "looked like a cinema village" and "[she] would not have been surprised to see Miss Dorothy Lamour strolling towards [her] in a brief but well-cut tiger skin, or to see some tawny Tarzan of the Apes striding off towards the forest for his next shot" $(118,70,123)$. The vision of Graham Greene as Douglas Fairbanks and the evocation of Tarzan both reveal Barbara's sense of unreality, but also her ability to mock herself, her cousin, and their journey as a whole. This mockery of self and others and, by implication, the colonial worldview, is also seen quite early in Too Late to Turn Back when Barbara reflects on the knives and "housewives" she and Graham take to Africa. The knives are "completely useless, for [the Africans] made far better ones themselves", while the housewives, little containers with needles and different coloured threads, which they keep until they get to "the really primitive parts", are even more useless, since "it gradually dawned on us that the natives there would have nothing they could possibly sew" (40), presumably since they wear few or no clothes. Barbara comments: "It was one of those mistakes that one cannot understand afterwards ever having made" (40), and it is a mistake which, significantly, is not registered in Graham's text, perhaps because of the ignorance of Africa and Africans that it suggests.

Like Graham Greene, Barbara uses the "seedy" trope, but more rarely. She describes the village of Toweh Ta as "an unpleasant mixture of the extremely primitive and the worst bits of a seedy civilisation" ([1981] 1990b, 151). Similarly, in Duogobmai, the chief is "a nasty, depraved old man, with a crafty, mean face, and obviously at some time must have known civilisation of the coast" (54-55). His village has "nothing simple and unspoilt" about it; "It was twisted and bad. There was an atmosphere of decay everywhere" which Barbara Greene can "only suppose ... had come up somehow from the semi-civilisation of the coast" (55). Like Graham, she sees the influence of European civilisation on the life of the interior as corrupting the natural simplicity of its customs and its people. When she sees the young prostitute she fears "that 'civilisation' was about to destroy some of the charm and beauty of the village life", since she feels sure "that at some time [the young girl] had been down to the coast and that she had known white men" (179). She also fears that an improvement in health care "would be the last thing that civilisation would bring [the people of the interior]", since "Their minds and instincts would be warped first by the shoddiness of second-rate ideas, while their poor bodies would be left to go on rotting" (179-180), and she sees the beginning of "civilisation" (again, the word is in quotation marks in the text) as "a few badly built houses with broken and rusty tin roofs, a few half-castes lying asleep in the dust with a bottle of cane juice at their sides" (192). She does not share her cousin's fascination with the "seedy" coast, finding nothing to admire or interest her in Monrovia, although she admits that this may have been because of her tiredness (200).

While both Greenes use comparisons of Africa to England or Europe to approach the unfamiliar through the familiar, Graham Greene often deploys allusions to create an intensely textualised version of Africa that reflects his own anxieties about developments in European civilisation. Conversely, Barbara's comparisons often view Africa through the lens of popular culture in such a way as to mock both herself and Graham and to undermine the vision of the journey as 
masculine imperialist quest. One shared feature of their narratives, however, is their use of the African as child metaphor, although even here there are significant differences.

\section{The white man (and woman) in Africa}

Both Greenes use the imperialist metaphor of the carriers as children, ${ }^{3}$ but its use is reinforced in Graham Greene's text by a network of public school references, which emphasise his uppermiddle-class background and his anxiety about the authority he has to exercise in the colonial context. Moreover, while Journey Without Maps continually refers to "the white man" and "the black man", such colour and racial consciousness is relatively rare in Barbara's text. Graham Greene explicitly raises the issues of colonial exploitation and guilt; in the interior he is forced to play the role of the stereotypical "white man in Africa", but feels inadequate and guilty in doing so, while Barbara both mocks and admires her cousin's imperial role in his relations with the carriers: as a woman, she is distanced from the pressure of her imperial role in a way not possible for Graham, and although, at times, she shares his view of the carriers as children, playing the maternal to his paternal role, her text also debunks parental images of colonial authority when she represents both Graham and herself as helpless individuals at the mercy of external forces which they cannot control.

In Journey Without Maps, when the carriers threaten to strike, Greene fears the challenge to his authority, saying: "I suppose it is the thought which strikes every new prefect at school, but I had never been a prefect; I had never before so abjectly depended on other people's obedience"; later, having won the battle, he decides that "The character of a carrier is childlike. He enjoys the moment. He cannot connect cause and effect", adding that the carriers "could be distracted, too, as easily as children" ([1936] 2002, 115, 116). ${ }^{4}$ Later the carriers become "schoolboys who are testing a new master's discipline", while Greene is the "weak master who knows his own weakness and bluffs it out with a new form, unable to recognize who is truthful and who is not, alienating the honest by classing them with the dishonest" (122). Similarly, he sees Laminah and Alfred's teasing of a monkey as the behaviour of "bullies at school with a new boy who couldn't hit back" (117). Towards the end of the journey, Greene describes the dressing-down he gives to a young chief who fails to provide food for the carriers:

I was very Imperialist, very prefectorial as I told him that a chief must be judged by his discipline, that he ought not to allow his headman to disobey him. He couldn't tell my satiric self-criticism as the ghost of Arnold of Rugby addressed his head prefect through my lips. (188)

Furthermore, on occasion Greene also uses the pidgin English traditionally associated with the imperialist role, as when he resolves a dispute among the carriers and boys with "the absurd imperial phrase, which never failed to silence them, "Palaver finished"' (217). While Greene may see his performance as "satiric self-criticism", and find the "imperial phrase" "absurd", in the context of 1930s Liberia, he is forced into the imperialist role despite his misgivings about it.

It is true that Greene feels guilty, both about his treatment of the carriers and about colonial policy more generally. He admits that his carriers are underpaid ([1936] 2002, 148), that he is ashamed of "exploiting them like all their other masters" (149), that he feels "guilty of a meanness" when he pays off one hardworking carrier with "a very small dash" (178), and that being carried in the hammock because he has fever makes him feel guilty since "It was too close to using men as animals for me to be happy" (214). He also criticises the colonial administrators of Sierra Leone and the Firestone Company of Liberia. The former he describes as "the real rulers", who 
were supposed to be there for the good of the ruled. It was these men who had so much to answer for: the wages, for example, of the platelayers on the little narrow-gauge line which runs up to Pendembu near the French and Liberian borders. (43-44)

The Firestone Company is also criticised for its monopoly, its forced labour, its inadequate wages, although they are higher than those of the British Government in Sierra Leone and twice those Greene pays his carriers (Shelden 1994, 162), and for the fact that it forces its labourers to buy rice from its own stores at inflated prices (232-233). However, these criticisms of imperial and colonial practices occur mainly in connection with the Coast or with Sierra Leone, as I have already noted above.

Despite Greene's criticism of the colonial authorities, his text is characterised throughout by race or rather colour consciousness, expressed in terms like "a/the white man" or similar expressions (see Greene [1936] 2002, 17, 18, 20, 39, 41, 43, 47 in the first 50 pages alone). Greene is conscious that he does not always live up to what is expected of him "as a white man". Of the rail journey to Kailahun, he writes: "Nobody in England had warned me of the centre compartment, although I now understood that as a white man I should have made some effort to engage it", so on leaving Sierra Leone "it was a relief to enter the Republic [of Liberia] and no longer feel that I was a member of the ruling race" (52). One version of this colour leitmotif is especially significant, that is, the repeated claims that the Greenes are "the first white people to be seen in living memory" (65), or words to that effect, in the villages through which they pass (see also 117, 125, 128, 153, 189). This reinforces the impression which Greene wishes to create of an adventurous foray into the unknown, although as I have shown above, the Greenes followed Sir Alfred Sharpe's route for over half their journey.

While Barbara Greene also uses the child metaphor for the carriers, it is partially qualified by the fact that she refers to herself as a lost and half-witted child and to both herself and Graham as "puppets" or "dolls" not in control of their own destinies ([1981] 1990b, 56). She uses notations of colour more sparingly than Graham: in the first 50 pages of her text there are only four references to colour $(10,14,33,45)$, and there is no discussion of colonial politics in her book. Instead she focuses on the people she and Graham encounter as individuals, often establishing relations of reciprocity and friendliness with them, in contrast to Graham's relations of authority dictated by his imperial role as leader of the expedition.

Barbara's use of the "child" metaphor indicates both appreciation of the carriers' childlike qualities of naivety, simplicity and honesty, and irritation at their laziness, especially their cry of "Too far, too far" (Greene [1981] 1990b, 31 and see 51, 68, 177), although she does admit that they are occasionally right in their judgment of distances (31-32). Like Graham she describes them as "child-like creatures, easily amused, living in the moment" (32, and see 54, 89), and she clearly sees herself and Graham as playing parental roles. On two occasions she refers explicitly to Graham Greene as a father figure, describing the carriers lying around him after the day's trek, joking and laughing "while he, like a benevolent father, would smile kindly upon them" (68), and pitying their bewilderment when they finally leave the Greenes at the coast: "The men looked bewildered, for they felt lost now without Graham, who had been their father for so long" (193). As Graham Greene notes, they "led a patriarchal life on trek" (Greene [1936] 2002, 137).

Barbara also both compares herself to a mother figure and yet also at times suggests the falsity of the trope of the African as child. When Amadu performs a dance, she says:

I was glad to see that it won admiration, for I felt rather like a mother showing off her child. He had been good to us and I wanted so desperately that he should do well before all these strangers. (Greene [1981] 1990b, 100) 
But this colonial image of the mother as authority figure is immediately undermined since three paragraphs later Barbara compares herself to

the half-witted child I had once seen somewhere. It had a large notice tied round its neck on which was written in big letters, "I want to get to such and such an address in London." Every one was helpful as possible [sic], the child was pushed about in various directions, and I felt quite sure that it would arrive safely eventually. We, too, equally helpless, I felt would arrive safely one day. (100-101)

Barbara's image of herself as a "half-witted child" might seem to endorse the conventional view of the feminine as inscribed in masculine psychiatric discourse, that is, in Elaine Showalter's words, of the view of women as "typically situated on the side of irrationality, silence, nature, and body, while men are situated on the side of reason, discourse, culture, and mind" ([1985] 1993, 3-4). However, Barbara then goes on to describe both herself and Graham as "equally helpless" (101, my emphasis), which is a much less conventional rhetorical move and which subverts the imperialist authority of both Greenes as colonial parental figures. At other moments, moreover, Barbara represents both herself and Graham as examples of "the fools of this world" who need "a kind of saint" to guard them (11), or as

Two small white puppets, pulled by strings out of their usual course, and dragged hither and thither into incongruous situations... Two white dolls ... wondering where the strings would pull them next. ... So useless, so ineffective - just paper dolls. (56)

At such moments both the Greenes are constructed as passive beings, not in the least in control of their own actions, a construction which both contrasts with and mocks Graham Greene's selfpresentation as self-conscious and conflicted authority-figure. The element of mockery in such writing offers an example of a discourse which runs counter to the discourse of masculine and imperialist superiority of works like Journey Without Maps, even if Barbara's text quite often endorses conventional gender roles.

This implicit challenge to the values of masculine imperialist discourse can also be seen in Barbara Greene's mockery of Graham's relations with the boys and the carriers. She explains that he usually treated the carriers "exactly as if they were white men from our own country", talking to them in "long complicated phrases" which they did not understand, although she claims that "they liked him" (Greene [1981] 1990b, 68). However, on their journey in the interior, as part of the stereotypical imperial role he is forced to play, Graham resorts to pidgin English to settle arguments among the men. Barbara reports one such occasion: drunk, Graham listens "majestically for a few minutes", then, "lifting up his hand he said, 'Palaver finished.' Then (swaying, oh so slightly) he walked away. It was a superb performance" (96). As the word, "performance" indicates, Barbara Greene is aware that Graham is playing a role, an awareness which is even clearer when, again called upon to resolve another dispute, Graham listens, thinks, and then "for the last time he became the Great White Chief, bringing out his usual phrase with all its familiar success. 'I agree with Amadu. Palaver over"' (183). Just as she has demystified the adventure trope in relation to their journey, Barbara mocks the imperialist dimension of Graham Greene's role-playing. As a woman she is able to look on from the sidelines, although she also shares some of the imperialist attitudes Graham exhibits, like the perception of the carriers and the boys as children, a perception perhaps reinforced by their shared upper-middle-class upbringings in houses with servants.

\section{Conclusion}

While Journey Without Maps reinscribes many of the familiar tropes of Africanist discourse about Africa with all their imperialist implications, despite Greene's feelings of guilt about 
the imperial role he plays with the carriers, and despite his criticisms of colonialism and capitalism, Too Late to Turn Back uses, demystifies, and mocks some of these tropes, like those of the "Adventure in the Wilds" and the "Great White Chief" (Greene [1981] 1990b, 43, 183). The climaxes of the two books and their endings also suggest the differences between the two Greenes' visions of Africa.

The climax of the personal quest in Journey Without Maps might be said to be Greene's discovery of his own will to live. Very ill with fever, he discovers "a passionate interest in living" which is "like a conversion" (Greene [1936] 2002, 213). There is no such moment of epiphany in Too Late to Turn Back, which nonetheless ends with the assertion, "It was worth it" (Greene [1981] 1990b, 205). On the day on which she fears Graham might die, Barbara admits in her diary to feeling a little tired but continues:

Feeling very fit indeed. This weather agrees with me, but the carriers all have bad headaches. (175)

Like many other women travellers before her (Foster 1990, 12), Barbara thrives on her journey in Africa. The mention of her feeling "very fit indeed" is one of several similar remarks $(83-84,113$, 188) which contrast with the notations of illness in Graham's text.

The endings of the two books also reveal the two travellers' different perspectives. The end of Journey Without Maps returns once again to the tropes of Africa as virgin land, of darkness, and of "going back". This time the image of darkness takes the form of a child in an English tenement crying, ignorant of "what the dark may conceal in the way of lust and murder" (Greene [1936] 2002, 250). As Greene looks at his suitcases and his "loot" from Africa, the final words of the book (from "the graves" on in the passage cited here) are a quotation from Ralegh: "There, I thought ... was as far back as one needed to go, was Africa: the innocence, the virginity, the graves not opened yet for gold, the mine not broken with sledges" (250). Ironically, although Greene is quoting from Ralegh's conclusion where he is describing the material advantages for England in colonising Guiana (Ralegh [1596] 1997, 196), in Greene's text the passage reconstructs "Africa" as a fabulous place removed from but also threatened by history, since while it is "not yet" destroyed, it is threatened with destruction. At the end of Journey Without Maps Greene accepts that Africa as "the true primitive source" (244) is no longer available; the European traveller must go home with his nostalgia for what has been lost. In contrast with the highly wrought, self-conscious finale of her cousin's book, Barbara's ends much more simply. She waits for a train to London, feeling "alone in the world" (Greene [1981] 1990b, 204), but when she is rescued by the porter who offers her coffee and warmth, "suddenly the world seemed a happier place" (205): her book ends with human contact and reciprocity, this time in the form of coffee and sympathy from the porter, someone as far removed from her in terms of class as the Africans were distant from her in terms of race. Graham's book ends with the evocation of the lost childhood innocence of both the individual and the race. Graham Greene evokes the beginnings of the colonial worldview through his allusion to Ralegh which both historicises and mythologises the British colonial experience in Africa, while Barbara ends on a much simpler note of self-assertion, replying to the porter's "Wherever 'ave you been to?" with the words, "It was worth it" (205).

\section{Acknowledgements}

An earlier version of this essay was given as a plenary talk at Middle East Technical University (METU), Ankara, Turkey; many thanks to METU for permission to reproduce some of that material here. I would also like to thank the anonymous readers for Studies in Travel Writing for their comments. 


\section{Notes}

1. Theroux (1990: xxi) and Sherry (1989: 509) both give Barbara's age as 23, but Shelden (1994: 160) gives it as 27 .

2. Schweizer (2001: 150) sees the final references to The Waste Land and to Ralegh as the result of "ideological anxiety" caused by "the return to previously rejected ideological "premises".

3. For examples of this trope from Richard Burton, Lionel Phillips, and Cecil Rhodes, see Ashcroft (2000: 190-191).

4. Blanton (1997: 66) and Dedet and Petr (1992: 334) also note Greene's use of the imperialist "child" trope, while Schweizer notes its use by both Greenes but especially by Barbara, although he does not note the public school allusions (2001: 72-73).

\section{References}

Ashcroft, Bill. 2000. "Primitive and Wingless: The Colonial Subject as Child." In Dickens and the Children of Empire, edited by Wendy S. Jacobson, 184-202. New York: Palgrave Macmillan.

Blake, Susan. 1991. "Travel and Literature: The Liberian Narratives of Esther Warner and Graham Greene." Research in African Literatures 22 (2): 191-203.

Blake, Susan. 1992. “A Woman's Trek: What Difference Does Gender Make?” In Western Women and Imperialism: Complicity and Resistance, edited by Nupur Chaudhuri and Margaret Strobel, 19-34. Bloomington: Indiana University Press.

Blanton, Casey. 1997. "The Modern Psychological Journey: Graham Greene.” Chap. 4 In Travel Writing: The Self and the World. New York: Twayne.

Baudelaire, Charles. (1857) 1991. Les Fleurs du mal. Paris: Flammarion.

Brantlinger, Patrick. 1986. "Victorians and Africans: The Genealogy of the Myth of the Dark Continent." In "Race", Writing, and Difference, edited by Henry Louis Gates, Jr., 185-222. Chicago: University of Chicago Press.

Burton, Richard F. (1863) 1991. Wanderings in West Africa. 2 vols. New York: Dover.

Butcher, Tim. 2012. "Our Man in Liberia." History Today 60 (10). np. Accessed November 28, 2011. $\mathrm{http}: / / w w w . h i s t o r y t o d a y . c o m / t i m-b u t c h e r / g r a h a m-g r e e n e-o u r-m a n-l i b e r i a$

Dedet, André and Christian Petr. 1992. "Le Voyageur en Afrique et son regard sur 1'Autre." Journal of European Studies 22: 323-335.

Dodd, Philip. 1982. "The Views of Travellers: Travel Writing in the 1930s." Prose Studies 5 (1): 127-138.

Fabian, Johannes. (1983) 2002. Time and the Other: How Anthropology Makes Its Object. New York: Columbia University Press.

Foster, Shirley. 1990. Across New Worlds: Nineteenth-Century Women Travellers and Their Writings. New York: Harvester Wheatsheaf.

Freud, Sigmund. (1919) 2003. The Uncanny. New York: Penguin.

Freud, Sigmund. (1930) 1961. Civilization and Its Discontents. New York: Norton.

Fussell, Paul. 1980. Abroad: British Literary Traveling Between the Wars. Oxford: Oxford University Press.

Gikandi, Simon. 1996. Maps of Englishness: Writing Identity in the Culture of Colonialism. New York: Columbia University Press.

Greene, Barbara. (1981) 1990a. "Foreword to the New Edition." Too Late to Turn Back, vii-xvi. London: Penguin.

Greene, Barbara. (1981) 1990b. Too Late to Turn Back. London: Penguin.

Greene, Graham. (1936) 2002. Journey Without Maps. London: Vintage.

Greene, Graham. (1947) 1969. "The Lost Childhood." In Collected Essays, 13-18. Harmondsworth: Penguin.

Greene, Graham. 1980. Ways of Escape. London: Penguin.

The Holy Bible. https://www.lds.org/scriptures/bible?lang=eng

Kingsley, Mary. [1897] 1988. Travels in West Africa. Boston: Beacon Press.

McEwan, Cheryl. 2000. Gender, Geography and Empire: Victorian Women Travellers in West Africa. Aldershot: Ashgate.

Mercer, Wendy S. 1999. "Gender and Genre in Nineteenth-Century Travel Writing: Léonie d'Aunet and Xavier Marmier." In Travel Writing and Empire: Postcolonial Theory in Transit, edited by Steve Clark, 147-163. London: Zed Books.

Meyers, Jeffrey. 1990. Graham Greene: A Revaluation: New Essays. London: Macmillan.

Mikkonen, Kai. 2007. "The 'Narrative is Travel' Metaphor: Between Spatial Sequence and Open Consequence." Narrative 15 (3): 286-305. doi:10.1353/nar.2007.0017 
Mikkonen, Kai. 2008. "“It Is Not the Fully Conscious Mind which Chooses West Africa in Preference to Switzerland': The Rhetoric of the Mad African Forest in Conrad, Céline and Greene." Comparative Critical Studies 5 (2-3): 301-315. doi:10.3366/E1744185408000475

Miller, Christopher L. 1985. Blank Darkness: Africanist Discourse in French. Chicago: University of Chicago Press.

Mills, Sara. 1994. "Knowledge, Gender, and Empire." In Writing Women and Space: Colonial and Postcolonial Geographies, edited by Alison Blunt and Gillian Rose, 29-50. New York: Guilford Press.

Nesbit, Edith. (1902) 1994. Five Children and It. Oxford: Oxford University Press.

Nesbit, Edith. (1904) 1959. The Phoenix and the Carpet. London: Penguin.

Ralegh, Walter. (1596) 1997. The Discoverie of the Large, Rich and Bewtiful Empyre of Guiana. Norman: University of Oklahoma Press.

Said, Edward. [1978] 1995. Orientalism. London: Penguin.

Schwartz, Adam. 2002. "From Granite to Grass: Graham Greene, Travel and the Primitive." Renascence 55 (1): 25-45. doi:10.5840/renascence20025514

Schweizer, Bernard. 2001. Radicals on the Road: The Politics of English Travel Writing in the 1930s. Charlottesville: University Press of Virginia.

Schweizer, Bernard. 1998. "Graham Greene and the Politics of Travel.” Prose Studies 21 (1): 95-124.

Shelden, Michael. 1994. Graham Greene: The Enemy Within. New York: Random House.

Sherry, Norman. 1989. The Life of Graham Greene Volume I: 1904-1939. London: Jonathan Cape.

Showalter, Elaine. [1985] 1993. The Female Malady: Women, Madness, and English Culture, 1830-1980. London: Virago.

Siegel, Kristi, ed. 2004. Gender, Genre, and Identity in Women's Travel Writing. New York: Peter Lang.

Thacker, Andrew. 2002. "Journey with Maps: Travel Theory, Geography and the Syntax of Space." In Cultural Encounters: European Travel Writing in the 1930s, edited by Charles Burdett and Derek Duncan, 11-28. New York: Berghahn Books.

Theroux, Paul. [1981] 1990. "Introduction." In Too Late to Turn Back. Barbara Greene, xxi-xxxiii. London: Penguin.

Torgovnick, Marianna. 1990. Gone Primitive: Savage Intellects, Modern Lives. Chicago: University of Chicago Press.

Wittman, Emily O. 2011. "A Circuit of Ordeals: Nostalgia and the Romance of Hardship in Graham Greene's Journey Without Maps and Ernest Hemingway's Green Hills of Africa.” Prose Studies 33 (1): 44-61. doi:10.1080/01440357.2011.568780

Wordsworth, William. (1807) 2012. "The World Is Too Much with Us.” In The Norton Anthology of English Literature. Volume 2. edited by Stephen Greenblatt, 347. New York: Norton. 